\title{
Agroforestry as a Pathway to Climate-Smart Agribusiness: Challenges and Opportunities to Smallholder Farmers in Developing Countries
}

Getahun Kassa ( $\nabla$ zgetah@gmail.com )

Hawassa University https://orcid.org/0000-0001-6042-1454

Systematic Review

Keywords: Agroforestry systems, climate-smart agriculture, inclusive business models, smallholders

Posted Date: February 2nd, 2022

DOI: https://doi.org/10.21203/rs.3.rs-184084/v2

License: (9) This work is licensed under a Creative Commons Attribution 4.0 International License. Read Full License 


\section{Abstract}

Agroforestry systems have been increasingly important in recent years as they have provided smallholder farmers with new commercial options and ecosystem-based adaption solutions. While being an ecofriendly practice has gained agroforestry systems popularity as a climate-smart agriculture practice, exploiting their investment potential requires understanding their key features as a climate-smart business. The purpose of this review is to increase smallholder incentives from adding climate-smart value to agroforestry in developing countries. The review assesses the challenges and opportunities of agroforestry as a climate-smart practice with the intent to guide investors, development practitioners, and researchers to foster economically, socially, and ecologically viable climate-smart agribusiness. Based on the review, the finding reveals market failure, delayed return on investment, insecure tenure, and lack of institutional support as the challenges hindering agroforestry business. On the other hand, availability of green finance, growing public-private partnerships, environmentally friendly preferences, growing demand for food and sustainable fuelwood, and agritourism are identified as opportunities to scale-up agroforestry as a climate-smart business. Ultimately, by creating a productive, resilient, and low-emission land-use for smallholder farmers, agroforestry systems can be an effective and efficient pathway towards climate-smart agribusiness and to the achievement of the Global Goal of Sustainable Development.

\section{Introduction}

Agroforestry is a sustainable landscape practiced by more than 1.2 billion people worldwide (Dawson et al., 2013). It received high attention as a resource-efficient and environment-friendly land-use practice (Jose and Gordon, 2008). In the same vein, the concept of agroforestry bases on the expected role of onfarm and off-farm tree production in supporting sustainable land-use and natural resource management (Nair, 2014). Agroforestry focuses on the role of trees in agricultural landscapes to achieve the economic, ecological, and social needs in today's world (Garrity, 2004). From a natural science point of view, agroforestry values in terms of its ecosystem services: soil enrichment, biodiversity conservation, improvement in air and water quality, and carbon sequestration (Jose, 2009). Unlike other types of conservation practices where land is taken out of production, agroforestry is 'productive conservation' (Gold et al., 2004). From an economic point of view, agroforestry systems have typical features: a) long planning horizons, $b$ ) irregular cost and revenue occurrences, and c) fixed tree components along with crop or livestock components (Godsey, 2008). Meanwhile, the basic premise of an agroforestry system in economic terms is that its total net benefit is greater where joint rather than singular production (monocropping) exists (Betters, 1988). Agroforestry systems are also playing an important role as part of the so-called "climate-smart" landscape that simultaneously embraces mitigation and adaptation policies and programs (Montagnini, 2017).

Agroforestry, with its multiple environmental and economic benefits, can help the agriculture and forestry sectors find innovative solutions to present-day problems: including low profitability, environmental impacts, and negative public perception (Baets et al., 2007). Agroforestry often produces specialty products for markets that enable farmers to make a decent income while simultaneously conserving soil, 
water, and other natural resources (Gold et al., 2004). Agroforestry projects support a variety of rural development resources, thus leading to more stable agribusinesses and rural communities (Vrahnakis et al., 2015). According to Montagnini and Metzel (2017) among a total of 17 Sustainable Development Goals to be achieved over the next 15 years, agroforestry can make a significant contribution: SDG 2 on hunger, as shown in this article, SDG 5 on gender equality, SDG 6 on clean water, SDG 7 on affordable, clean energy, SDG 10 on reducing inequalities within and among countries, SDG 13 on climate action, and SDG 15 on sustainable forestry and restoration. The overall goals of an agroforestry (AF) system are: to improve the existing situation through increasing production and productivity, to generate a sustained agricultural products base, to reduce environmental damage, and to raise the living standard of the human population (Betters, 1988). Agroforestry systems can, thus, be a good alternative for achieving sustainable and climate-smart agriculture (Somarriba et al., 2017). Ultimately, by integrating agriculture and forestry, agroforestry endeavors to optimize economic, environmental, and social benefits.

Nowadays, agroforestry has gained popularity because of its appeal as an ecologically sustainable approach to agricultural development. Agroforestry offers an alternative management system to conventional agricultural practices that meet the requirements for reduced environmental impact whilst improving the potential for farm business profitability. In recent days, agroforestry provides commercial opportunities in local and international markets for farmers from developing countries. Despite the opening up of new market opportunities for agroforestry products and services, their role in business enterprise development and rural development is not properly acknowledged. The lack of recognition for the existing agroforestry practices can be attributed to a lack of understanding of the important role agroforestry practices currently play in local economies and the potential of these systems for future agricultural development (Drew et al., 2004). In other words, because of the limited academic attention so far, science currently does not help to inform decision-makers on how to design climate-smart business models that effectively target the SDGs (Rosenstock et al., 2020). It is, therefore, important for decisionmakers to acknowledge the potential of agroforestry as a pathway to climate-smart agribusiness. The exploitation and maximization of the economic benefit of agroforestry as a climate-smart agriculture investment, however, is difficult without understanding the nature and characteristics of the agroforestry business. To fill this knowledge gap, I conducted a systematic review that focused on characterizing the business of agroforestry. To this effect, the review elaborates on the benefits of agroforestry systems, the challenges, and opportunities in undertaking agroforestry investment.

\section{Materials And Methods}

An extensive systematic review of scientific publications was applied to this study on agroforestry systems as a pathway to climate-smart agribusiness. To guarantee the quality of the material scientific reviews, and publications have been chosen based on the credibility of the journals they are published. Academic search engines such as Web of Science Direct, JSTOR, Google Scholar, and Research gate were selected to identify relevant publications on agroforestry systems. Written records since the 1980s were systematically retrieved using a 5-way strategy that combined search terms (keywords) related to 1) Agroforestry systems, 2) Agroforestry business, 3) Agroforestry Products Marketing, 4) Climate-Smart 
Agriculture, and 5) Economics of agroforestry. Retrieved papers were manually screened and shortlisted if the title and abstract indicated that they reported similar results in the English language. All of the retrieved papers were stored in a Mendeley database. Finally, 82 papers, including original researches, reviews, and book chapters, were reviewed and combined.

In compiling this review, I surveyed 231 peer-reviewed journal articles covering the period of $1980-2020$. From this initial set of articles, I reduced the number further to cover published agroforestry papers by setting keywords. This reduced the target number of peer-reviewed manuscripts to a total of 82 .

\section{Results And Discussion}

\section{Contributions of Agroforestry}

Agroforestry harnesses the concept of sustainable development through the provision of multiple goods and services. The functions of agroforestry classify as economic, ecological, and social. The fact that agroforestry can simultaneously address economic, ecological, and social objectives of sustainable development makes it an attractive land use practice in both developing and developed countries.

\section{Economic Functions}

Agroforestry is highly appreciated by farmers for its capacity to create a diverse farm economy and stimulating the entire rural economy (Walker, 2013). In light of increasing production, agroforestry supports the production of a wide range of products due to the diversity of planned species within the system (Smith et al., 2012). On the other hand, agroforestry has recently experienced a surge in interest, from the research and development communities, as a cost-effective means to enhance food security (Mbow et al., 2014). It plays a pivotal role in limited-resource households, who cannot subsist from their agricultural production, and who therefore achieve food security through engaging in a diversity of income-generating activities (Belsky, 1993).

In the context of macroeconomic contribution, agroforestry creates various jobs by supporting the emergence of farm-related rural employment and specialization (Ajijur et al., 2017). More specifically, agroforestry practices create employment opportunities with regards to the management of seedling farms, increased labor for pruning and harvesting of firewood, and other products from the tree stands (Herren et al., 2012). In terms of its contribution to national income accounting, the World Bank indicated that agroforestry contributed $29 \%$ to agriculture's gross domestic product (GDP) in developing countries (World Bank, 2008). Among the rural poor, the incorporation of a diverse variety of trees into agricultural systems, in general, can increase crop productivity, increase the incomes of smallholder farmers, and improve nutrition (WAC, 2008). The economic function of agroforestry ultimately helps sustain farm profitability and empower the rural economy from mixed trees garden.

Ecological Functions 
The soil-conservation and erosion-reduction roles of trees are one of the most widely acclaimed and compelling reasons for including trees on farming systems and farmlands that are prone to erosion hazards (Naire, 1985). Trees in agroecosystems can also enhance soil productivity through biological nitrogen fixation, efficient nutrient cycling, and deep capture of nutrients and water from soils (Naire, 2014). Apart from soil fertility enhancement and soil conservation, when compared with conventional and organic monocultures, agroforestry systems are crucial for biodiversity conservation (Wilson and Lovell, 2016). Agroforestry is used in several protected areas as buffer zones for alleviating pressure on forests, thereby reducing deforestation (Minang et al., 2011). Furthermore, evidence suggests that where farmers have incentives to plant trees and have access to information and planting material, they depend less on neighboring forests and are less likely to damage them (SWF, 2005). On the other hand, agroforestry has distinct benefits in terms of reduced greenhouse gas emissions and sequestering carbon in aboveground woody biomass (Burgess and Rosati, 2018). A large amount of carbon is sequestered by increasing the rotation age of trees and/or shrubs and by manufacturing durable products from them upon harvest (Jose, 2009). Regarding adaptation to climate change, agroforestry has the potential to moderate climate extremes, in particular high temperatures, as well as intra-annual climatic fluctuations (Mbow et al., 2014). Furthermore, agroforestry can be an appropriate technology in areas with fragile ecosystems and subsistence farming (Ranc et al., 2014). In severely degraded areas due to deforestation or intensive monocropping, agroforestry practices play a vital role in bringing back the biological productivity of the land by increasing soil fertility, enhancing water retention, and improving crop productivity (Kumar et al., 2015).

\section{Social Functions}

Agroforestry offers high social benefits in developing countries. From the vantage point of women, agroforestry provides good opportunities to women in terms of increased incomes and sustainable livelihoods (Kiptot and Franzel, 2012). Indeed, it is a suitable land management system to reduce gender inequalities related to natural resource access (Wekesa et al., 2018). In light of addressing the livelihood situations in developing countries, agroforestry also plays an important role in the livelihoods of poor people (Liu et al., 2019). Agroforestry is a pathway toward more resilient livelihoods for millions of African farmers whose livelihoods are threatened by climate change and land degradation (Mbow et al., 2014). More general, integrating trees into the agricultural landscape has the potential to impact the local economy through diversification of local products, diversification of rural skills, improvements to the environment, landscape diversification, and economic stability (Smith et al., 2012).

\section{Challenges and Opportunities of Agroforestry Investment}

The agroforestry business has many distinguishing features from most conventional farm businesses. Planners working with agroforestry projects need to be aware of the constraints which impinge upon the decision-making of the landowners.

\section{Challenges of Agroforestry Investment}




\section{A. Limited Private Sector Investment}

Agroforestry provides composite benefits to farmers, though some of these ecosystem goods do not generate an explicit financial incentive. For many landowners, the pleasure of owning and maintaining trees is an unprized benefit that is valued more than the revenue received from selling products from the trees (Centre for Agroforestry, 2013). The lack of functional markets that could monetize valuations of the avoided externality costs reduces the potential of many green investment programs, including agroforestry, to attract sufficient private investment (Herren et al., 2012). Private profitability analysis, in effect, does not include non-market ecosystem goods and services since these goods belong to public goods. Evidence suggests the indivisibility and non-exclusively attributes of public goods discourage landowners from considering agroforestry systems in their decision-making (Alavalapati et al., 2004).

\section{B. Long Payback Periods}

Agroforestry requires an upfront investment in terms of money and time, whilst the return on the investment is longer than for annual crops (Sharma et al., 2016). It takes three to six years before benefits begin to be fully realized in agroforestry systems (Russell \& Franzel, 2004). From a financing perspective, one of the most pressing problems of an agroforestry business is the negative cash flow in the short term while the owner waits for years to reap economic returns. This poses a challenge for smallholder farmers, especially in regions where the cost of capital and discounting factor is high (Ajayi et al., 2007). Similarly, as a result of the long period required for trees to pay off, local banks do not offer the long-term credit needed to service agroforestry investments (Gromko et al., 2017). In a nutshell, the private sector may be less enthusiastic about agroforestry due to the longer time frames often required for productivity improvements to deliver competitive economic returns on such investments (Herren et al., 2012).

\section{Poor Marketing and Value Addition Activities}

Agroforestry systems can help smallholder farmers attain higher productivity and sustainability; however, these achievements do not always translate into significantly larger financial returns to farmers due to difficulties in the value chain of the agroforestry products and access to the right markets (Montagnini, 2017). The diverse nature of agroforestry practices presents marketing challenges (USDA, 2019). Except for a few products, value chains for agroforestry products are poorly developed. As the added value of agroforestry is relevant to special products, it appears agroforestry added value is unclear to consumers (Hannachi et al., 2017). Furthermore, most agroforestry products lack connections to markets due to poorly developed policies that tend to focus on conventional agricultural methods such as monocropping systems (Agroforestry Network, 2020). Whilst conventional farm products have robust business interests that do not exist for agroforestry, the poorly developed business activities for agroforestry products are one of the greatest bottlenecks in exploiting the market potential of agroforestry enterprises.

D. Tenure Insecurity 
Land and tree tenure insecurity may be a key constraint to introduce long term investments such as agroforestry. Given the relationship between trees and tenure, evidence suggests that state action or inaction regarding a tenure system can enhance or discourage tree-planting and commercialization of tree crops (Bruce \& Fortmann, 1989). In the case of agroforestry, for instance, one might expect that secure land ownership would be a prerequisite for commercial agroforestry (Smith et al., 1998). This is because farmers require longer periods to test, adapt, and eventually adopt agroforestry technologies and practices (FAO and ICRAF, 2019). From the concept of investment, investors want to invest in land-use practices where the land title is secure. Unless there are improvements in land tenure for smallholder farmers, it is unlikely that they would take the full measure of investments that are justified by the economic returns over time (Herren et al., 2012). In light of tree tenure, farmers can be limited by heavy regulations regarding the management, harvest, and selling of trees (Dawson et al., 2013). Taking Ethiopia as a particular embodiment, there might be some restrictions imposed by the government to cut some tree products from farmlands. In a nutshell, failure to clarify and secure the tenure of agroforestry land can lead to weak incentives for adoption, inequitable distribution of benefits, and lackluster impacts that fail to justify investments (FAO and ICRAF, 2019).

\section{E. Institutional Problem}

Major barriers to promote agroforestry systems are the lack of support for such systems through public policies (Bishaw et al., 2013). Agricultural price supports or credit granted for certain agricultural activities, but hardly ever for trees, are also discouraging agroforestry adoption (FAO, 2013). Consequently, agroforestry has a de facto "orphan" status in many national government settings (Place et al., 2012). Though agroforestry involves various stakeholders and value chains across agriculture and forestry sectors, institutional mandates are often unclear and divided between agriculture and forestry ministries (Agroforestry Network, 2020). Experience indicates agroforestry is said to belong to many ministries theoretically; in practice, however, it belongs to none; which creates numerous legal, economic, and social barriers preventing the potential of agroforestry to be fully exploited (Dawson et al., 2013).

\section{Opportunities for Agroforestry Investment}

\section{i) Production Diversity and Reduced Risk}

Agroforestry has long been touted as a triple-win for smallholder farmers, with the potential to mitigate environmental damage, increase income, and improve climate resilience (Hughes et al., 2020). Agroforestry is important in rural livelihoods since it provides resilience to socioeconomic shocks through on-farm livelihood diversification (Namirembe et al., 2015). Concerning financial risk management, the returns from agroforestry systems are less risky than returns from monoculture (Harou, 1983) since agroforests can provide in the long-run a stable and diversified source of income (Torquebiau and Penot, 2006). Meanwhile, a diverse portfolio of agroforestry products permits revenue streams to spread out over the short-term, medium-term, and long-term (Wilson and Lovell, 2016). In this regard, unlike conventional monocropping, the combination of annual crops with trees ensure a stable income that is resilient to changes in economic conditions. In Indonesia, Murniati et al. (2001) found that households 
with rice-only farms had an intermediate income of $\$ 286$ per year, while those with farms composed of both rice land and mixed gardens had an income of $\$ 492$. Regarding the management of production risk, the replacement of monoculture crops by more diverse agroforestry systems often seen as a strategy to reduce the risk of pest and disease outbreaks (Schroth et al., 2000). Concerning marketing risk, agroforestry is more stable in the face of global market volatility than annual monocultures. The advantages of diversification in the face of market risks may be achieved by mixing enterprises on a coarse scale as well as by adopting a single enterprise that embodies intimately mixed components (Price, 1995). In West Africa, diversifying agroecosystems with integrated approaches such as agroforestry improves resilience to climate-related risks (Sinare and Gordon, 2015). In general, agroforestry can substantially reduce economic, and climate-related risks by growing a variety of crop components in the system.

ii) Agroforestry is a Low-cost System:

The main productive advantages of agroforestry systems are linked to better use of resources (Ranc et al., 2014). Agroforestry is an efficient strategy for capital-poor farmers wishing to intensify land use as land-holding size decreases (Arnold, 1987). Small parcels and marginal land can be well-suited to agroforestry practices since agroforestry makes the land more productive both spatially and temporally (USDA, 2019). To this effect agroforestry can be better characterized as a land-use system that meets the tree needs of rural communities, generates income, and stabilize land productivity for smallholder farmers.

Agroforestry provides products that the farmer would otherwise have to purchase (SWF, 2005). In terms of labor requirements, for instance, monocropping systems are a more labor-intensive farming system than the agroforestry-based system (Getahun, 2015). Whilst an advantage of agroforestry is that tree management operations can often be scheduled for slack periods of labor demand (Current et al., 1995). In terms of fertilizer requirement, agroforestry has the potential to increase farm productivity without reliance on large amounts of external inputs such as inorganic fertilizers and chemicals for pest and plant disease management (Wekesa et al., 2018). Similarly, one of the contributions of the tree component in an agroforestry system is through green manures which increase the productivity of agricultural field crops and the associated reduction in the cost of chemicals (Sangeetha and Shanmugam, 2015). Agroforestry systems, through the use of nitrogen-fixing trees, are providing options in Malawi that complement and reduce the need for inorganic nitrogen fertilizer. Accordingly, field trials in Malawi indicate that, once the beneficial tree cropping method has been established maize yields have increased between $54-76 \%$ compared with traditional practices (Garrity, et al. 2010). In a nutshell, Because the production and trading of Agroforestry tree products are based on traditional lifestyles, it is relatively easy for new producers to adopt this approach with minimal skills, little capital, and few needs for external inputs (Leaky et al., 2005).

iii) Carbon Revenue 
Carbon sequestration is part of an emerging market that pays landowners for certain environmental services (Beetz, 2011). As a carbon sink, agroforestry represents untapped potential to feasibly provide benefits from carbon schemes to poor smallholders in developing countries and to minimize the emission-reduction costs of developed countries (Walden et al., 2020). Evidence suggests that for smallholder agroforestry systems in the tropics, potential $C$ sequestration rates range from 1.5 to $3.5 \mathrm{Mg}$ C ha-1 yr-1 (Watson et al., 2000). In Ethiopia, a recent finding by Walden et al. (2020) indicated that the possibility of receiving carbon revenue increased the profitability of agroforestry by $0.5 \%$ when using the lowest utilized carbon price and carbon sequestration rate, and by $70 \%$ when using the highest price and highest sequestration rate of carbon.

One option to finance agroforestry adoption in developing countries is through biocarbon projects, under which land users receive payments for carbon sequestered on their land (Foster and Neufeldt, 2014). Taking into consideration the UNFCCC definition of forest, a lot of existing agroforestry systems worldwide could qualify to be an integral part of a REDD+ mechanism (Minang et al., 2011). Moreover, the World Bank has initiated the Community Development Carbon Fund and the Biocarbon Fund to link the enhancement of local livelihoods with C investment projects (Roshetko et al., 2006).

\section{iv) Enabling Environment}

In recent days, agroforestry received attention for an effective pathway to climate change adaptation and mitigation nationally and internationally. Agroforestry is recognized as a key mitigation strategy as a climate-smart agriculture response under the United Nations Framework Convention on Climate Change (UNFCCC) (Dawson et al., 2013). In the case of African countries, Agricultural Development and Investment Strategies developed under the CAADP (Comprehensive African Agricultural Development Programme) umbrella in 2010 and which also emphasized agroforestry (FAO, 2010). Likewise, recent announcements by Coca-Cola, Pepsi, and Del Monte, that they were all interested in investing to develop smallholder fruit market chains in East Africa are a sign of the potential upscaling of agroforestry opportunities with the private sector involvement (Place et al., 2012). Furthermore, the "Food for Progress" program in Cameroon is providing a wide range of training to farmers engaged in agroforestry and the domestication of indigenous fruits and nuts (Leakey, 2012). In the same vein, PUR Project has been developing and implementing agroforestry, agroecology, and capacity building projects in more than 50 countries with smallholding vanilla, cocoa, or coffee farmers. Starting in 2015, PUR Project started working in Ethiopia with smallholding coffee farmers on different activities.

\section{v) Eco-friendly Consumption}

The environmental friendliness of agroforestry practice is considered advantageous to farmers. Climatesavvy shoppers in the developed world are now more interested to consume farm products which pursue environmentally sustainable production system. Recently, there is a rapidly expanding demand for organic and other environmentally certified products (World Bank, 2008). To this effect consumers in importing countries are demanding commodities that comply with environmental, social, and governance standards (Dermawan et al., 2017). There are many reasons why people have environmentally friendly 
preferences, ranging from purely self-interest motives such as health risk avoidance to ethical and altruistic concerns about biodiversity, climate, or animal welfare (Carlsson et al., 2010). When managed as an organic farm product, the agroforestry system yields products that can receive remunerative price offers. By exporting agroforestry products, smallholder farmers can better exploit overseas market opportunities.

\section{vi) Energy Production}

Most poor rural communities in developing countries rely on firewood or charcoal for their energy needs as the vast majority of them lack access to electricity or affordable fossil fuels (Herren et al., 2012). Agroforestry through the use of pruning harvested periodically from multipurpose trees such as those produced for timber is making farmers self-sufficient with firewood (Njenga et al., 2019). In Tanzania, Sileshi et al. (2007) indicated that the yearly fuelwood production in the Chagga agroforestry home gardens is estimated at $1.5-3 \mathrm{~m}^{3}$ per ha. According to Jama et al. (2006), a tree fallows as small as 0.5 ha would provide the firewood needed for the family to cook for one year, saving women's time in collecting and carrying heavy loads. In Ethiopia, the parkland agroforestry users spent a mean of 1.56 ha per week to collect fuelwood; whereas the households that have not practiced agroforestry spent a mean time of 3.4hours per week, which is more than 2 folds (Hagos, 2020).

In the area of bioenergy production, agroforestry systems offer new ways for farmers to respond to the need for more renewable sources of energy (Beetz, 2011). Agroforestry systems can potentially augment bio feedstock production for bioenergy use (Patel-weynand et al., 2017). By providing modern alternatives to cooking fuel from waste biomass materials, agroforestry practices play an important role in meeting the Sustainable Development Goals (SDGs) of ensuring access to affordable, reliable, sustainable, and modern energy (Sharma et al., 2016).

vii) Agritourism

The rural landscapes of many rich biodiversity areas, such as small-scale farms, could attract tourism based on the pristine nature or traditional agricultural practices, or a combination of both (Herren et al., 2012). Barbieri and Valdivia (2010) indicated that agroforestry adoption is important as a means to increase the non-economic values of landscape beautification and maximization of recreational enjoyment. Evidence suggests the recreational value of the agroforestry landscape is providing opportunities in the area of agritourism that can benefit the general public and farmers (Smith et al., 2012; Valdivia et al., 2012). For farmers, agritourism has a positive impact on farm profits (Barbieri and Tew, 2016), and there may be benefits from enjoying and appreciating an agroforestry landscape for the general public (Mcadam et al., 2009).

A recent study in Ethiopia indicated that coffee tourism as a component of rural tourism would be a source for income diversification and maintenance of sustainable livelihood (Woyesa \& Kumar, 2020). In their report (Woyesa \& Kumar, 2020) indicated that like wine tourism in rural Europe, coffee growers in Ethiopia could manage packages of a rural landscape, scenery, and rural heritage on the working farm. In 
India, agrotourism helped to the improvement of farmers' income and contributed to educating the visitors and local communities on sustainable agriculture (Hamilpurka, 2012).

\section{Conclusion}

Agroforestry systems can provide multifunctional benefits to smallholder farmers and society at large. Agroforestry generates economic incentives to farmers from the joint interaction of trees and crops, and as well it generates social (intangible) benefits to the society through implementing environmentalfriendly practices. More generally, agroforestry systems are described as ecologically sound, economically viable, and socially just land-use practices. Ultimately, by creating a productive, resilient, and low-emission land-use for smallholder farmers, agroforestry systems serve as a pathway to climatesmart agribusiness. However, the long-term returns on investment and the lack of incentives for all the goods and services produced by landowners make agroforestry unfamiliar to traditional and risk-averse investors. Decision-makers must pay attention to the carbon footprints of agroforestry projects, collective action for market access, public-private partnerships for sustainable business development, and agritourism to create an enabling environment for agroforestry as climate-smart agribusiness.

\section{Declarations}

\section{Competing Interests}

The author declares that there is no competing interest.

\section{References}

Agroforestry Network. (2020). Agroforestry Value Chains and Market Systems. 1-8.

Ajayi, O. C., Akinnifesi, F. K., Sileshi, G., Chakeredza, S., \& Matakala, P. (2007). An economic framework for integrating environmental stewardship into food security strategies in low-income countries: a case of agroforestry in the southern African region. African Journal of Environmental Science and Technology: 1(4), 59-67. Available online at http://www.academicjournals.org/AJest.

Ajijur, S., Jette, R., Jacobsen, B., Robert, J., James, H., and Sunderland, T. (2017). Finding alternatives to swidden agriculture: does agroforestry improve livelihood options and reduce pressure on existing forests? Agroforestry Systems, 91(1): 185-199. https://doi.org/10.1007/s10457-016-9912-4.

Alavalapati, J. R. R., Shrestha, R. K., Stainbac, G. A., \& Matta, J. R. (2004). Agroforestry development: An environmental economic perspective. Agroforestry Systems 61: 299-310.

Arnold, J. E. M. (1987). Economic considerations in agroforestry. In: Steppler HA and Nair

PKR (ed) Agroforestry a decade of development. International Council for Research in Agroforestry, pp 173190. 
Baets, N. De., Gariépy, S., and Vézina, A. (2007). Portrait of agroforestry in Quebec. Executive summary. AAFC 10241E.

Barbieri, C., and Tew, C. (2016). Perceived Impact of Agritourism on Farm Economic Standing, Sales, and Profits. Travel and Tourism Research Association: Advancing Tourism Research Globally. https://scholarworks.umass.edu/ttra/2010/Oral/34.

Barbieri, C., and Valdivia, C. (2010). Recreational Multifunctionality and its implications for agroforestry diffusion. Agroforest Syst 79: 5-18. https://doi.org/10.1007/s10457-009-9269-z.

Beetz, B. A. E. (2011). Agroforestry: An Overview. 1-20. A project of the National Center for Appropriate Technology. http://www.attra.ncat.org/attra-pub/PDF/agrofor.pdf.

Belsky, J. M. (1993). Household Food Security, Farm Trees, and Agroforestry: A Comparative Study in Indonesia and the Philippines. Human Organization, 52(2): 130-141.

Betters, D. R. (1988). Planning optimal economic strategies for agroforestry systems. Agroforestry Systems 7: 17-31.

Bishaw, B., Neufeldt, H., Mowo, J., Abdelkadir, A et al. (2013). Farmers' Strategies for Adapting to and Mitigating Climate Variability and Change through Agroforestry in Ethiopia and Kenya. Forestry Communications Group, Oregon State University, $\quad$ Corvallis, Oregon.

Bruce, J. W., and Fortmann, L. (1989). Agroforestry: Tenure and Incentives. LTC Paper 135. Land Tenure Center, University of Wisconsin-Madison.

Burgess, P. J., and Rosati, A. (2018). Advances in European agroforestry: results from the AGFORWARD project. Agroforestry Systems, 92(4): 801-810. https://doi.org/10.1007/s10457-018-0261-3.

Carlsson, F., García, J. H., \& Löfgren, Å. (2010). Conformity and the Demand for Environmental Goods. Environ Resource Econ 47: 407-421. https://doi.org/10.1007/s10640-010-9385-2.

Current, D., Lutz, E., Scherr, S. J., Lutz, E., \& Scherr, S. J. (1995). The Costs and Benefits of Agroforestry to Farmers. The World Bank Research Observer 10(2): 151-180. http://www.jstor.org/stable/3986580.

Dawson, I. K, Place, F., Torquebiau, E et al. (2013). Agroforestry, food, and nutritional security. Background paper for the International Conference on Forests for Food Security and Nutrition, FAO, Rome, 13-15 May 2013.

Dermawan, A., Pramudya, E. P., Hospes, O., and Pachec, P. (2017). Trends and challenges for developing the next generation of business and finance schemes for smallholders. Center for International Forestry Research. http://www.jstor.com/stable/resrep16259. 
Drew, W. M., Alavalapati, J. R. R., and Nair, P. K. R. (2004). Determining Agroforestry Profitability Using the Policy Analysis Matrix: A Case Study from Pohnpei, Federated States of Micronesia. In: Alavalapati JRR \& Mercer DE (ed) Valuing Agroforestry Systems, pp 59 - 78.

FAO and ICRAF. (2019). Agroforestry and tenure. Forestry Working Paper no. 8. Rome.

FAO. (2013). Advancing Agroforestry on the Policy Agenda: A guide for decision-makers, by Buttoud, G., in collaboration with Ajayi, O., Detlefsen, G., Place, F., \& Torquebiau, E. Agroforestry Working Paper no. 1. Food and Agriculture Organization of the United Nations. FAO, Rome. 37 pp

FAO. (2010). "Climate-Smart" Agriculture. Policies, Practices, and Financing for Food Security, Adaptation, and Mitigation. FAO, Rome.

Foster, K., and Neufeldt, H. (2014). Biocarbon projects in agroforestry: lessons from the past for future development. Current Opinion in Environmental Sustainability 6:148-154.

http://dx.doi.org/10.1016/j.cosust.2013.12.002.

Garrity, D. P., Akinnifesi, F. K., \& Ajayi, O. C. (2010). Evergreen Agriculture: a robust approach to sustainable food security in Africa. Food Security 2: 197-214. https://doi.org/10.1007/s12571-010-0070-7.

Garrity, D. P. (2004). Agroforestry and the achievement of the Millennium Development Goals. Agroforestry Systems 61: 5-17.

Getahun, K. (2015). Profitability analysis and determinants of fruit tree-based agroforestry system in Wondo District, Ethiopia. African Journal of Agricultural Research 10(11): 1273-1280.

https://doi.org/10.5897/AJAR2014.9272.

Godsey, L. D. (2008). Economic Budgeting for Agroforestry Practices. AF1006 - 2008, University of Missouri Center for Agroforestry.

Gold, M. A., Godsey, L. D., \& Josiah, S. J. (2004). Markets and marketing strategies for agroforestry specialty products in North America. Agroforestry Systems 61: 371-382.

Gromko, D., Calo, I., UNIQUE forestry, and land use. (2017). Agroforestry business models: Investment opportunities in Costa Rica. San José, Costa Rica.

Hagos, K. A. (2020). Contribution of parkland agroforestry in supplying fuelwood and its main challenges in Tigray, Northern Ethiopia. African Journal of Agricultural Research 15(3): 483-491. https://doi.org/10.5897/AJAR2019.14477.

Hamilpurka, S. (2012). Agri-Tourism In Karnataka - Issues, Constraints, and Possibilities. International Journal of Research In Commerce, Economics \& Management, 2(7): $\quad$ 106-111. 
Hannachi, Y., Balaguer, F., Borek, R et al. (2017). Organizing added value of agroforestry. EIP- AGRI Focus Agroforestry. MINI PAPER 1: 1-6.

Harou, P. A. (1983). Economic Principles to Appraise Agro-Forestry Projects. Agricultural Administration 12: 127-139.

Herren, H. R., Bassi, A. M., Tan, Z., \& Binns, W. P. (2012). Green Jobs for a Revitalized Food and Agriculture Sector. Natural Resources Management and Environment Department Food and Agriculture Organization of the United Nations.

Hughes, K., Morgan, S., Baylis, K., Oduol, J., Smith-dumont, E., Vågen, T., \& Kegode, H. (2020). Assessing the downstream socio-economic impacts of agroforestry in Kenya. World Development, 128, 104835. https://doi.org/10.1016/j.worlddev.2019.104835.

Jama, B., Elias, E., \& Mogotsi, K. (2006). Role of agroforestry in improving food security and natural resource management in the drylands: a regional overview. Journal of the Drylands: 1(2), 206-211.

Jose, S. (2009). Agroforestry for ecosystem services and environmental benefits: an overview. Agroforest Systems 76: 1-10. https://doi.org/10.1007/s10457-009-9229-7.

Jose, S., and Gordon, A. M. (2008). Ecological Knowledge and Agroforestry Design: An Introduction. In: Jose S, and Gordon AM (ed) Toward Agroforestry Design: An Ecological Approach.

Kiptot, E. \& Franzel, S. (2012). Gender and Agroforestry in Africa: Are Women Participating? In: Nair PKR and Garrity D (ed) Agroforestry - The Future of Global Land Use. Advances in Agroforestry 9: 463 - 496. http://www.springer.com/series/6904.

Kumar, C., Begeladze, S., Calmon, M., and Saint-Laurent, C. (2015). Enhancing food security through forest landscape restoration: Lessons from Burkina Faso, Brazil, Guatemala, Viet Nam, Ghana, Ethiopia, and the Philippines. Gland, Switzerland: IUCN. pp. 5-217.

http://dx.doi.org/10.2305/IUCN.CH.2015.FR.2.en.

Leakey, R. R. B. (2012). Multifunctional Agriculture and Opportunities for Agroforestry: Implications of IAASTD. In Nair PKR, and Garrity D (eds) Agroforestry - The Future of Global Land Use. Advances in Agroforestry, Volume 9. Springer Dordrecht Heidelberg New York London.

Leakey, R. R. B., Tchoundjeu, Z., Schreckenberg, K., Shackleton, S. E., \& Shackleton, C. M. (2005). Agroforestry Tree Products (AFTPs): Targeting Poverty Reduction and Enhanced Livelihoods. International Journal of Agricultural Sustainability 3(1): 1-23. http://dx.doi.org/10.1080/14735903.2005.9684741.

Liu, W., Yao, S., Wang, J., \& Liu, M. (2019). Trends and Features of Agroforestry Research Based on Bibliometric Analysis. Sustainability 11: 1-15. http://dx.doi.org/10.3390/su11123473. 
Mbow, C., Van Noordwijk, M., Luedeling, E et al. (2014). Agroforestry solutions to address food security and climate change challenges in Africa. Current Opinion in Environmental Sustainability 6: 61-67. https://doi.org/10.1016/j.cosust.2013.10.014.

Mcadam, J. H., Burgess, P. J., \& Graves, A. R. (2009). Classifications and Functions of Agroforestry Systems in Europe. In: Rigueiro-Rodríguez et al (ed) Agroforestry in Europe: Current Status and Future Prospects, pp $21-41$.

Minang, P. A., Bernard, F., van Noordwijk, M., Kahurani, E. (2011). Agroforestry in $\quad$ REDD+: Opportunities and Challenges. ASB Policy Brief No. 26, ASB Partnership for the Tropical Forest Margins, Nairobi, Kenya.

Montagnini, F. (2017). Introduction: Challenges for Agroforestry in the New Millennium. In the F. Montagnini (ed.), Integrating Landscapes: Agroforestry for Biodiversity Conservation and Food Sovereignty, Advances in Agroforestry 12, Chapter 1: 3 - $10 . \quad$ https://doi.org/10.1007/978-3-31969371-2_1.

Montagnini, F., and Metzel, R. (2017). The Contribution of Agroforestry to Sustainable Development Goal 2: End Hunger, Achieve Food Security and Improved Nutrition, and Promote Sustainable Agriculture. In the Montagnini, F (eds) Integrating Landscapes: Agroforestry for Biodiversity Conservation and Food Sovereignty. Advances in Agroforestry 12, Chapter 2: 11 - 45. https://doi.org/10.1007/978-3-319-693712_2.

Murniati, Garrity, D. P., \& Gintings, A. N. (2001). The contribution of agroforestry systems to reducing farmers' dependence on the resources of adjacent national parks: a case study from Sumatra, Indonesia. Agroforestry Systems 52: 171-184.

Nair, P. K. R. (2014). Agroforestry Systems and Environmental Quality: Introduction. https://doi.org/10.2134/jeq2011.0076.

Nair, P. K. R. (1985). Agroforestry in the Context of Land Clearing and Development in the Tropics. Working paper no. 33. Paper presented to the Inaugural Workshop on the Land Clearing and Development Soil Management Network, International Board for Soil Research and Management (IBSRAM), 26 August 02 September 1985 Jakarta, Indonesia.

Namirembe, S., McFatridge, S., Duguma, L et al. (2015). Agroforestry: an attractive REDD+ policy option? AGROFORESTRY - TEEBAGRIFOOD. www.teebweb.org.

Njenga, M., Gitau, J., liyama, M., Jamnadassa, R., Mahmoud, Y., Karanja, N. (2019). Innovative biomass cooking approaches for sub-Saharan Africa. Afr. J. Food Agric. Nutr. Dev. 19(1): 14066-14087.

Patel-weynand, T., Bentrup, G., Schoeneberger, M., Karel, T. H., \& Nair, P. K. R. (2017). Challenges and Opportunities. In: Michele MS, Gary B, and Patel-Weynand T (ed) Agroforestry: Enhancing Resiliency in 
U.S. Agricultural Landscapes Under Changing Conditions. 131-142. USDA. https://doi.org/10.2737/WOGTR-96.

Place, F., Ajayi, O. C., Torquebiau, E., Detlefsen, G., Gauthier, M., \& Buttoud, G. (2012). Improved Policies for Facilitating the Adoption of Agroforestry. In: Kaonga MLeckson (ed) Agroforestry for Biodiversity and Ecosystem Services - Science and Practice, pp 113 - 128.

Price, C. (1995). An economic evaluation of financial and non-financial costs and benefits in agroforestry development and the value of sustainability. Agroforestry Systems 30: 75-86.

Ranc, S. \., Makovskis, K., Lazdi, D., \& Daugaviete, M. (2014). Analysis of economic, social, and environmental aspects of agroforestry systems of trees and perennial herbaceous plants. Agronomy Research 12(2): 589-602.

Rosenstock, T. S., Lubberink, R., Gondwe, S., Manyise, T., \& Dentoni, D. (2020). ScienceDirect Inclusive and adaptive business models for climate-smart value creation \$. Current Opinion in Environmental Sustainability, 42: 76-81. https://doi.org/10.1016/j.cosust.2019.12.005.

Roshetko, J. M., Lasco, R. D., \& Angeles, M. S. D. (2006). Smallholder agroforestry systems for carbon storage. Mitigation and Adaptation Strategies for Global Change. https://doi.org/10.1007/s11027-0059010-9

Russell, D., and Franzel, S. (2004). Trees of prosperity: Agroforestry, markets, and the African smallholder. Agroforestry Systems 61: 345-355.

Sangeetha, R., and Shanmugam, T. R. (2015). External benefit and external cost in the economics agroforestry systems in northwestern parts of Tamil Nadu. International Journal of Commerce and Business Management, Volume 8 (1): 28-35. https://doi.org/10.15740/HAS/IJCBM/8.1/28-35.

Schroth, G., Krauss, U., Gasparotto, L., Duarte Aguilar, J. A., and Vohland, K. (2000). Pests and diseases in agroforestry systems of the humid tropics. Agroforestry Systems $\quad$ 50: $\quad$ 199-241.Available online: https://www.researchgate.net/publication/226282729.

Sharma, N., Bohra, B., Pragya, N., Ciannella, R., Dobie, P., \& Lehmann, S. (2016). Bioenergy from agroforestry can lead to improved food security, climate change, soil quality, and rural development. Food and Energy Security 5(3):165-183. https://doi.org/10.1002/fes3.87.

Sileshi, G., Akinnifesi, F. K., Ajayi, O. C., Chakeredza, S., Matakala, P. W., Programme, S. A., Agricultural, C., \& Box, P. O. (2007). Contributions of agroforestry to ecosystem services in the miombo ecoregion of eastern and southern Africa. African Journal of Environmental Science and Technology: 1(4), 68-80. Available online at http://www.academicjournals.org/AJes.

Sinare, H., \& Gordon, L. J. (2015). Ecosystem services from woody vegetation on agricultural lands in Sudano-Sahelian West Africa. "Agriculture, Ecosystems and Environment," 200, 186-199. 
https://doi.org/10.1016/j.agee.2014.11.009.

Smith, J., Pearce, B. D., \& Wolfe, M. S. (2012). Reconciling productivity with protection of the environment: Is temperate agroforestry the answer? Renewable Agriculture and Food Systems: 28(1): 80-92. https://doi.org/10.1017/S1742170511000585.

Smith, N., Dubois, J., Current, D., Lutz, E., \& Clement, C. (1998). Agroforestry Experiences in the Brazilian Amazon: Constraints and Opportunities. The Pilot Program to Conserve the Brazilian Rain Forest, Brasilia. Brazil.

Somarriba, E., et al. (2017). Trees on Farms for Livelihoods, Conservation of Biodiversity and Carbon Storage: Evidence from Nicaragua on This "Invisible" Resource. In the Montagnini, F (eds) Integrating Landscapes: Agroforestry for Biodiversity Conservation and Food Sovereignty. Advances in Agroforestry 12, Chapter 15: 369 - 393. https://doi.org/10.1007/978-3-319-69371-2_2.

SWF (State of The World's Forests). (2005). Realizing the economic benefits of agroforestry: experiences, lessons, and challenges. pp 88-97.

The Centre for Agroforestry. (2013). Economics of Agroforestry. The University of Missouri, The Global Centre for Agroforestry, Entrepreneurship and the Environment, Agroforestry Academy.

Torquebiau, E., and Penot, E. (2006). Ecology Versus Economics in Tropical Multistrata Agroforests. In: Kumar BM and Nair PKR (ed) Tropical homegardens: A Time Tested Example of Sustainable Agroforestry, 269-282.

USDA. (2019). Enhancing Rural Economies Through Agroforestry: Assessing Emerging Opportunities. USDA National Agroforestry Center, Miscellaneous Publication No. 1617.

Valdivia, C., Barbieri, C., \& Gold, M. A. (2012). Between Forestry and Farming: Policy and Environmental Implications of the Barriers to Agroforestry Adoption. Canadian Journal of Agricultural Economics. https://doi.org/10.1111/j.17447976.2012.01248.x

Vrahnakis, M., Nasiakou, S., Kazoglou, Y., \& Blanas, G. (2015). A conceptual business model for an agroforestry consulting company. Agroforestry Systems. https://doi.org/10.1007/s10457-015-9848-0.

WAC (World Agroforestry Centre). (2008). Agroforestry for food security and healthy ecosystems. Annual Report 2007-2008, Nairobi, Kenya.

Walden, P., Ollikainen, M., \& Kahiluoto, H. (2020). Carbon revenue in the profitability of agroforestry relative to monocultures. Agroforest Syst 94: 15-28. https://doi.org/10.1007/s10457-019-00355-x.

Walker, B. K. (2013). The Environmental Benefits of Agroforestry. Pp 1-5. https://www.azocleantech.com/article.aspx?ArticlelD=354. 
Watson, R., et al. (2000). Land Use, Land-Use Change, and Forestry. Intergovernmental Panel on Climate Change (IPCC), Special report. Cambridge Univ. Press. New York.

Wekesa, A., Malmer, A., Schaffer, C et al. (2018). Scaling up Agroforestry: Potential, Challenges, and Barriers. A review of environmental, social, and economic aspects at the farmer, community, and landscape levels. Agroforestry Network.

Wilon, M. H., and Lovell, S. T. (2016). Agroforestry - The Next Step in Sustainable and Resilient Agriculture. Sustainability 8: 1-15. https://doi.org/10.3390/su8060574.

World Bank. (2008). World development report 2008: agriculture for development. International Bank for Reconstruction and Development (IBRD) and World Bank, Washington DC.

Woyesa, T., \& Kumar, S. (2020). Potential of coffee tourism for rural development in Ethiopia: a sustainable livelihood approach. Environment, Development, and Sustainability. https://doi.org/10.1007/s10668-020-00610-7.

\section{Tables}

Table 1: Matrix of Inclusion/ Exclusion of Articles 
Key Terms Relevance of Key Term

Agroforestry The focus is agroforestry
Included if

It explains one of the three pillars of agroforestry benefits (economic, social, or ecological)

\begin{tabular}{|c|c|c|}
\hline $\begin{array}{l}\text { Climate- } \\
\text { Smart } \\
\text { Agriculture }\end{array}$ & The focus is on farm trees & If it is linked to agroforestry \\
\hline $\begin{array}{l}\text { Developing } \\
\text { Countries }\end{array}$ & $\begin{array}{l}\text { The research mainly } \\
\text { considers developing } \\
\text { countries }\end{array}$ & It is within the context of developing countries. \\
\hline $\begin{array}{l}\text { Smallholder } \\
\text { farmers }\end{array}$ & & If it is linked to smallholder farmers \\
\hline $\begin{array}{c}\text { Years of } \\
\text { Publication }\end{array}$ & & $\begin{array}{l}\text { The published articles are between the years } \\
\text { from the } 2000 \text { s and } 2021 .\end{array}$ \\
\hline Language & & English \\
\hline $\begin{array}{l}\text { Types of } \\
\text { Articles }\end{array}$ & & $\begin{array}{l}\text { Books, Book chapters, Original research } \\
\text { articles, Review articles, Working papers }\end{array}$ \\
\hline
\end{tabular}

\section{Figures}




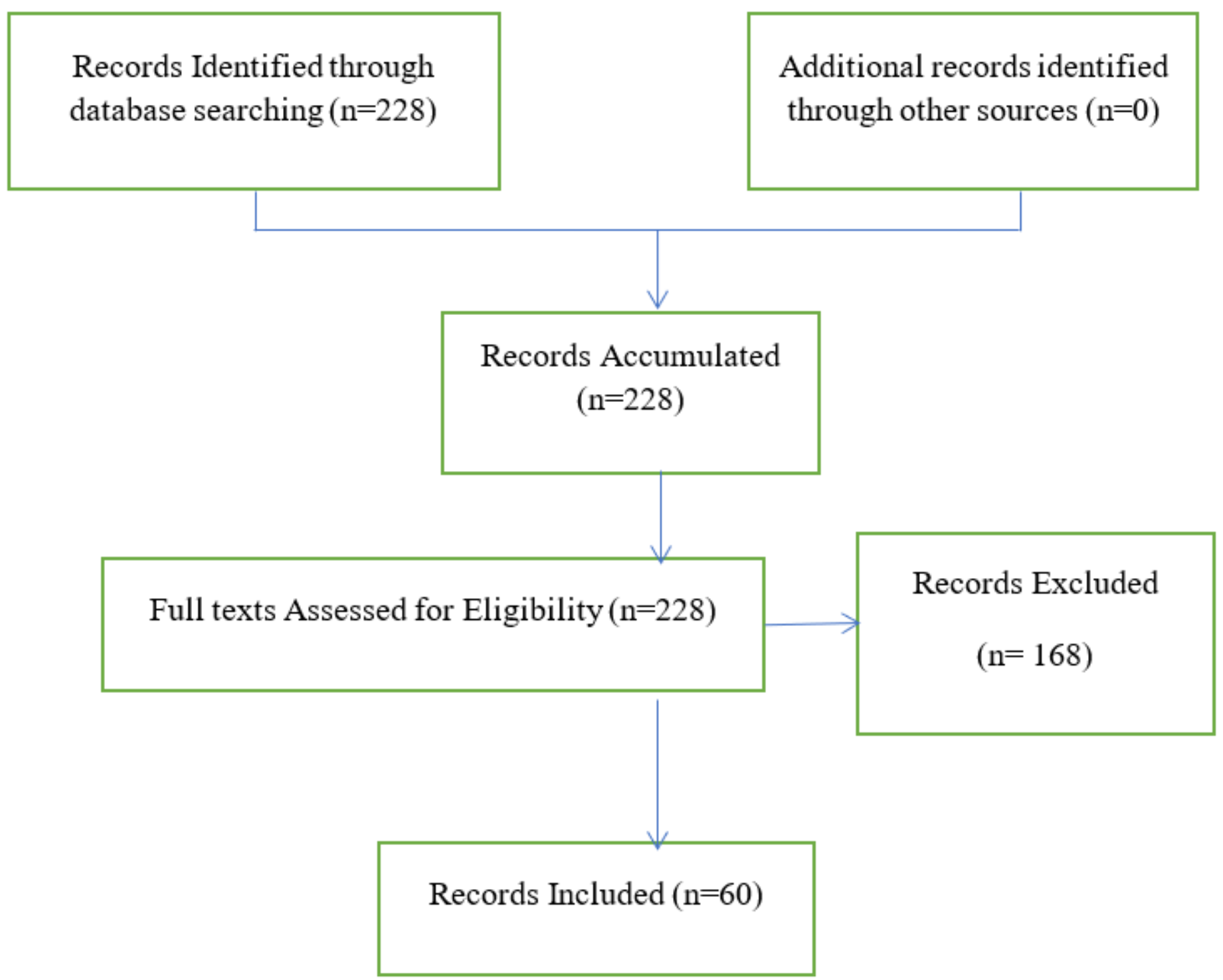

Figure 1

PRISMA Flow Diagram for Selecting Records 


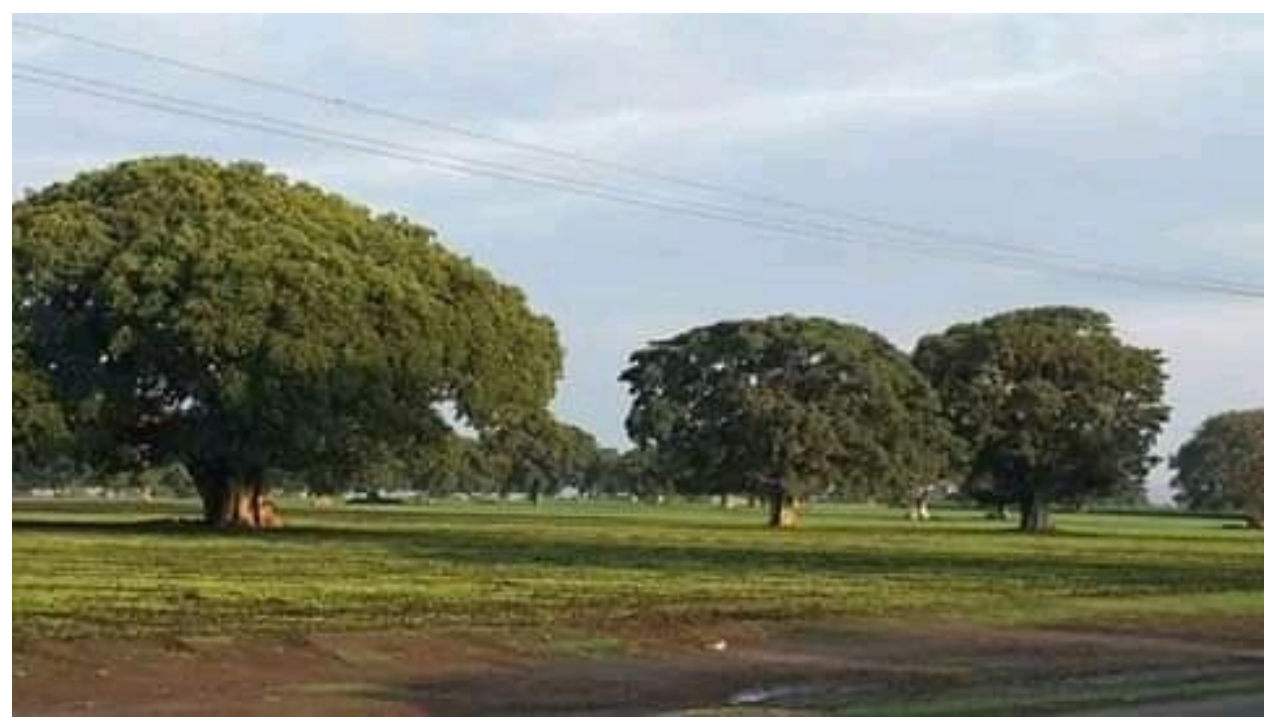

Figure 2

Pristine Agroforestry Landscape in Ethiopia with the potential for agritourism 